DOI: 10.22616/REEP.2019.005

\title{
The Influence of New Public Governance on the Development of Distributed Leadership in Educational Institutions
}

\author{
Dalia Dambrauskiene, Mg. oec. \\ Šiauliai University, Lithuania. \\ damdalia@splius.lt
}

\begin{abstract}
Distributed leadership is the idea that has been much discussed in the last decade. Meanwhile, the main problem of modern public governance evolutionary process is transformation from new public management to new public governance. The aim of the paper is to reveal the influence of new public governance and its implementation in practice on the development of distributed leadership in educational institutions. Based on theoretical research data, it is possible to state that currently, distributed leadership is the dominant idea of management. Lithuanian legal documents, the administrative environment, and specifics of institutions' activity create vast possibilities for development of distributed leadership in these organisations. The ideas of new public governance and distributed leadership of educational institutions are closely interlinked, as both are characterized by the following factors: decentralized management, collegial organizational structure, leadership as interaction. They both face similar challenges, i.e. the problem of "empowering" society / community, the issue of responsibility and accountability. The implementation of leadership ideas in Lithuanian educational institutions is not strictly regulated. Therefore, each organization can independently make decisions in order to optimize the decisions of the organization, or to take no action if the obvious organizational and structural changes in the organization are not required by the institutions controlling the activities of educational institutions.
\end{abstract}

Keywords: distributed leadership, educational institution, head, management, new public governance.

\section{Introduction}

The Lithuanian Progress Strategy "Lithuania 2030" (National Progress Strategy ..., 2013) emphasizes the necessity for the whole Lithuanian society to change in order to become the country of smart society and economy, smart governance promoting leadership. According to D. Dambrauskiene and L. Liukineviciene (2017), these strategic aspirations result in the necessary changes in the governance of the state and the public sector that meets the needs of society and efficiently uses resources. The educational sector is not an exception, where, in implementing this strategy, a closer concentration of human resources, more active employment of the resources of the organization and local community, other organizations that can contribute to the achievement of the goals are important. The changing environment not only changes the goals of public sector, but also changes the attitude towards the leaders of public sector organizations, their role in the organization and local community. A number of amendments and supplements, which have strengthened the role of the communities of educational institutions, and which have changed the role and position of the heads of educational institutions, have recently been carried out in the Law on Education of the Republic of Lithuania (Law on Education, 1991). They have established the new regulations for the assessment of the activities of heads of state (except higher education) and municipal schools, deputyheads for education, heads of the departments organizing education, the five-year term of office of heads has been introduced. Under the change of state regulatory acts, the individual organizations have to change as well. In order to achieve sustainable change in educational organizations, only the leadership of the heads of educational institutions is no longer sufficient. The need for other type of management culture in educational institutions is becoming relevant: the heads should pay attention to the development of abilities and possibilities not only of their own leadership but also of other members of the community (Valstybine svietimo 2013-2022 metu strategija, 2014; Geros mokyklos koncepcija, 2015). In Lithuania, leadership in educational institutions has been analysed quite comprehensively in the last decade. The project "Time for Leaders", which was initiated by the Ministry of Education and Science, and which has been carried out since 2009 (Lyderiu laikas, 2019), has significantly contributed to the dissemination of leadership ideas in Lithuania. The investigation of leadership in Lithuanian educational institutions is relevant because often these institutions become the main and most important ones in the development of leadership culture not only in institutional but also in local communities. 
The idea of distributed leadership has recently been the most researched leadership in educational institutions (Bolden, 2011). Meanwhile, in the past two decades, the researchers of public sector have focused their studies on the transformation of new public management into the analysis of new public governance.

This article aims to answer the question of how the new public governance and its implementation in practice contribute to the development of distributed leadership in educational institutions? The object of the research: the distributed leadership of educational institutions. The aim of the research is to reveal the influence of new public governance and its implementation in practice on the development of distributed leadership in educational institutions. The research tasks:

1. To summarize at the theoretical level the scientific approach to distributed leadership and its specificity in educational institutions.

2. To analyse the legal and administrative possibilities of the development of distributed leadership of educational institutions in Lithuania.

3. To reveal the links of between new public governance and distributed leadership of educational institutions.

\section{Methodology}

The research undertaken for this article is theoretical and based on a study and synthesis of the existing literature on the topic. The scope of the literature consulted includes management literature and articles specifically on distributed leadership and new public governance. The analytical content analysis of theoretical literature and other sources (strategic documents, legal acts, administrative documents) has been chosen for the implementation of the research tasks in order to concentrate and generalize theoretical insights, to find the opportunities for the development of distributed leadership in educational institutions, as well as to discern the new aspects of distributed leadership.

\section{Results and Discussion}

\section{The concept of distributed leadership}

The idea of distributed leadership has been very popular for the last few decades. This topic is the object of interdisciplinary research, it is being investigated not only by managers but also by psychologists, sociologists, educologists, and philosophers. According to P. Gronn (2000), for the first time, the term distributed leadership was used by C.A. Gibb (1954), who analysed the changes of the processes affected by non-formal and formal groups as well as the differences between one-person focused leadership and distributed leadership. According to A.L. Hill (2008), although the concept of distributed leadership appeared in the literature in the second half of the 20th century, there were no definitions of this term until the 21 st century. Systematic reviews of distributed leadership reveal that the term 'distributed leadership' holds a diversity of meanings, which demonstrate the ambiguity of leadership as a concept (Hill, 2008). According to R. Bolden (2011), the concept of distributed leadership has some common theoretical and practical origins with such concepts as 'shared', 'collective', 'collaborative', 'emergent' and 'co-leadership'. However, according to R. Bolden (2011), there are several essential differences in how these terms are used in different literature, their relative prevalence is different, they vary among countries and sectors. According to R. Bolden (2011), the popularity of the concept of distributed leadership has grown since 2000, especially in the education sector. According to L. Drysdale and D. Gurr (2017), the terms 'collective', 'shared' and 'distributed' leadership are often used synonymously.

According to A. Harris (2010), the popularity of distributed leadership has been empirically grounded, its positive impact on organizational and educational outcomes has been proven, it is characterized by representative and normative power. The concept of distributed leadership in the education sector has been developed by investigating the expression of this leadership in general education schools (Murphy et al., 2009; Harris, 2012; Spillane, 2015).

According to A. Harris (2010), distributed leadership is a form of leadership when the organization is influenced and decisions are made by several individuals working together, and not by one person. According to R. Elmore (2000), distributed leadership is when individuals share their skills, competences, and the nature of the work they perform in an organization - they learn from each other, communicate and collaborate. The participation of community members in the organization's activities, support 
for the initiative, involvement in decision-making, the distribution of power and activity among different members of the organization, formal and informal leaders (Leithwood et al., 2006; Harris, 2010; Duif, Harrison, van Dartel, 2013) are important factors as well. Distributed leadership is the responsibility and accountability for the individual contribution to collective outcomes (Elmore, 2000; Duif, Harrison, van Dartel, 2013). Another important aspect in developing distributed leadership in the organization is the high level of trust in employees (Harris, 2012). According to the researchers, the trust in the organization is created by the moral values of its members, attitudes, credibility, repetitive actions, individual relationships and trust-based atmosphere of the organization.

According to K. Leithwood (Leithwood et al., 2006), the result of distributed leadership and its impact on the organization depend on the type of distributed leadership: 1) planned distributed leadership; 2) self-contained distributed leadership; 3) demanded distributed leadership. A. Harris (2010) identified different strategies for distributed leadership: surface, middle and deep level of distributed leadership. When the deep level is reached, changes are observed in the organization's culture - the distribution of leadership becomes a working standard. According to T. Duif with colleagues (Duif, Harrison, van Dartel, 2013), seven dominant dimensions of distributed leadership can be distinguished: school structure, strategic vision, values and beliefs, communication and collaboration, decision making, responsibility and accountability, the initiative.

However, according to K. Leithwood (Leithwood et al., 2006), the concept of distributed leadership does not mean that formal management structures, formal leaders in organizations are unnecessary. In the authors' opinion, formal leaders are important, but more important are horizontal relationships, leadership as interaction, creation of space for other's leadership. A. Harris (2012) highlights the importance of formal leaders and observes that, in developing the distributed leadership at schools, various changes begin in the head's office. Whether it will be allowed to develop the initiatives of other individuals, or the initiative will be suppressed also depends on formal leaders (Murphy et al., 2009). School administration should foster distributed leadership in the school in order to foster professional learning and implement innovations (Butkevica, Zobena, 2017).

To sum up, it can be stated that organizational structure is important for the development of distributed leadership in the organization; a common strategic vision; the value-based approach of organization community favourable for distributed leadership; professional sharing of skills with each other; communication and cooperation to achieve the goals of the organization; initiative support; high confidence in each other; taking responsibility and accountability for their own activities and collective outcomes; the distribution of power between formal and informal leaders, and so on.

\section{Legal and Administrative Opportunities for the Development of Distributed Leadership of Educational Institutions in Lithuania}

According to D. Dambrauskiene and L. Liukineviciene (2017), in the documents formalizing changes in the state's educational policy the aspiration is seen to improve organizational management, interaction with local communities, social partners, and other educational institutions. The obvious shift of education policy in Lithuania to the development of leadership, as well as the development of distributed leadership in educational institutions is reflected in the following documents:

Lithuania's Progress Strategy "Lithuania 2030" (National Progress Strategy..., 2013) focuses on smart governance, i.e. the development of leadership and management competences in central and local government institutions and communities.

The National Lithuanian Education Strategy 2013-2022 (Valstybine svietimo 2013-2022 metu strategija, 2014), indicates that the dynamic interaction between educational institutions and the members of society in creating smart society is an essential factor for success. It is emphasized that leadership should involve the abilities of members of education sector and social partners to reach the aim of education, whilst educational management has to become more expedient and communal.

The Law on Education of the Republic of Lithuania (Law on Education, 1991) emphasizes the importance of interaction with the community of an educational institution, democratic governance of an institution, cooperation-based relationship, taken transparent decisions, and the information provided for the members of the community. Since 2017, the amendments to the Law on Education have introduced the new requirements for heads of educational institutions: the impeccable reputation of the head of 
education institution has been emphasized, the five-year term of office has been introduced, and it has been refused of the certification of heads

The Concept of Good School (Geros mokyklos koncepcija, 2015) emphasizes that management and leadership have to be shared. It is emphasized that the major part of decisions is made by school's community, its different members manage activities, their personal initiative is promoted. The distributed leadership is emphasised, i.e. the development of leadership skills is promoted at school, giving all members of the community the freedom to show initiative, take responsibility for initiatives, decisions, and their implementation. Leaders involve and promote community to debate, think and act creatively.

In Lithuania, considerable attention is paid to the qualification requirements for the heads of state and municipal educational institutions (except for higher education institutions) (Kvalifikaciniu reikalavimu valstybiniu..., 2011). The individuals who want to be heads of educational institutions have to selfevaluate their competencies at the National School Assessment Agency. The general competences of the applicants and the competences in the field of management are assessed. Although neither leadership nor distributed leadership is mentioned in these documents, it is evident that the heads face with the requirement that is also featured in distributed leadership (as managerial competences). Considering personal effectiveness, the following factors are emphasized: openness, respect for others, tolerance for social diversity, positivity, responsibility and honesty, initiative and so on. In terms of one more general competence - managing people, the ability to form and manage teams is mentioned, to work in a team, the ability to encourage and delegate, the ability to motivate and inspire, the ability and willingness to educate people, to reveal their potential, to provide support. Moreover, one of the management competences management of education and learning covers the community, strengthening of its provisions, and the joint implementation of strategies. This raises the need for distributed leadership in the educational institutions.

In conclusion, it can be stated that these normative legal documents, indicate the state's desire to conduct the changes of values in educational institutions, to strengthen the role of communities in the management of organizations, and to change the culture of management of educational organizations. This external change is a prerequisite for organizational leaders to change the culture of organizations. However, the implementation of leadership ideas in Lithuanian educational institutions is not strictly regulated. It enables each organization to purposely engage in strategic actions at micro level in order to achieve the most optimal decisions in a particular organization, or take no actions, and only simulate changes if the institutions coordinating the activities of educational institutions or the community itself do not require a clear cultural and structural change in an organization.

\section{The Interfaces of New Public Governance and Distributed Leadership of Educational Institutions}

In the decision making by new public governance the need for a consensus and each individual's participation dominate as well as common values, goals, forms of formal and informal power, involvement of various stakeholders in service creation, service and loyalty to the institution. Then in terms of distributed leadership in educational institutions, the same factors dominate as well.

Considerable attention during the development of public administration models has to be given to the qualification requirements for employees and especially for heads, the assessment of their competencies. However, the formation of conditions for the development of other individuals' initiatives changes the role of the formal leader in the organization. The basis of value-oriented organization is recognition of any value and any style of behaviour; therefore, harmonization of values plays a significant role in development of an organization (Ivanova, Ignatjeva, 2018).

A similar approach to mutual interaction, decision making, organizational culture, management hierarchy, responsibility/accountability and head's role can be seen in new public governance and features of distributed leadership (Table 1). As noted by D. Dambrauskiene and L. Liukineviciene (2017), the formation of a new organizational culture begins when the head assesses the existing culture by comparing it with the desired new organizational culture, and later transforming the culture: by developing and supporting the leadership of teachers and further by leading the distributed leadership (Figure 1). The statistical data provided on the website of the National School Assessment Agency (which conducts the assessment of the candidates for the heads of educational institutions) shows that from the 1st January 2017 until the 6th February 2018, the evaluations of competences of 393 individuals who aimed to be the heads of educational institutions were conducted. Only 86 candidates (i.e. 22 per 
cent) met the requirements of a sufficient level (Nacionaline mokyklu vertinimo..., 2018). Even the heads who already have managerial experience and qualification category barely overcame the assessment of competences: the competences of the heads who have the third qualification category were rated at a satisfactory level -27 per cent, the competences of the heads with the second category -38 per cent, and the heads who have the first qualification category (the highest) -62 per cent.

Table 1

The comparison of the features of new public governance model and the features of the distributed leadership in educational institutions

\begin{tabular}{|c|c|c|}
\hline & $\begin{array}{l}\text { Features of new public } \\
\text { governance }\end{array}$ & Features of distributed leadership \\
\hline $\begin{array}{l}\text { Mutual } \\
\text { interaction }\end{array}$ & $\begin{array}{l}\text { Constructive interaction, active } \\
\text { community }\end{array}$ & $\begin{array}{l}\text { Professional sharing of available skills with } \\
\text { each other, learning from each other, } \\
\text { communication and collaboration }\end{array}$ \\
\hline $\begin{array}{l}\text { Decision } \\
\text { making }\end{array}$ & $\begin{array}{l}\text { Involvement of employees in } \\
\text { decision-making, their } \\
\text { "empowerment" }\end{array}$ & $\begin{array}{l}\text { Each individual's participation in the } \\
\text { organization's activities and decision- } \\
\text { making, initiative support }\end{array}$ \\
\hline $\begin{array}{l}\text { Organizational } \\
\text { culture }\end{array}$ & $\begin{array}{l}\text { Collegial. Democracy, openness, } \\
\text { transparency, pluralism, } \\
\text { citizenship, lack of corruption }\end{array}$ & $\begin{array}{l}\text { Collegial. High confidence in each other. } \\
\text { Distribution of activities among different } \\
\text { employees of the organization }\end{array}$ \\
\hline $\begin{array}{l}\text { Management } \\
\text { hierarchy }\end{array}$ & $\begin{array}{l}\text { The power of the head is } \\
\text { dispersed }\end{array}$ & The power of the head is dispersed \\
\hline $\begin{array}{l}\text { Responsibility/ } \\
\text { accountability }\end{array}$ & $\begin{array}{l}\text { Accountability, cross-sectoral } \\
\text { social responsibility }\end{array}$ & $\begin{array}{l}\text { Responsibility and accountability for } \\
\text { individual's contribution to collective } \\
\text { outcomes }\end{array}$ \\
\hline Head's role & Head's function is to coordinate & $\begin{array}{l}\text { Leadership as interaction. Horizontal } \\
\text { relationships }\end{array}$ \\
\hline
\end{tabular}

Source: Compiled according to R.F. Elmore (2000); K. Leithwood (Leithwood et al., 2006), A. Harris (2010);

T. Duif, Harrison Ch, N. van Dartel (Duif, Harrison, van Dartel, 2013)

The competence of strategic thinking and management of changes was rated the lowest. Obviously, there is a lack of coherence between the requirements for heads' qualification categories and the criteria for the assessment of heads' competences. Therefore, the question arises whether the requirements for candidates are timely and match the maturity not only of the individual candidates, but also the maturity of all the community of educational institutions.

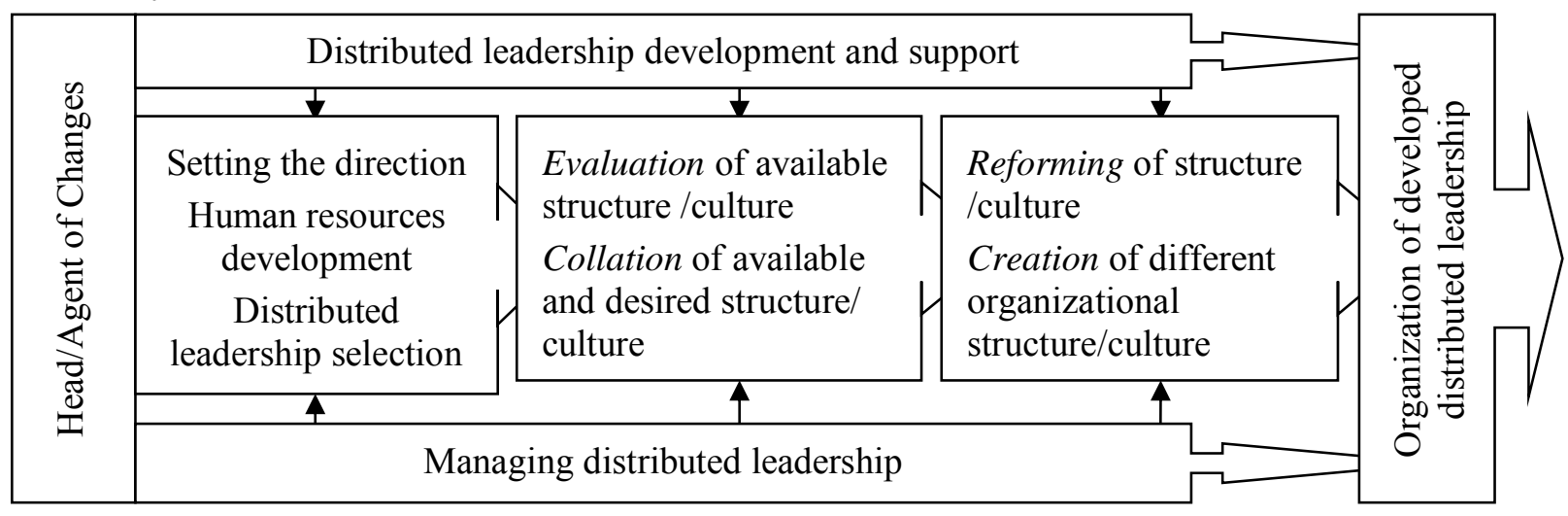

Figure 1. The development of heads' distributed leadership in an organization, created by

D. Dambrauskiene and L. Liukineviciene (2017).

The new public governance focuses on the decentralization of government, the involvement of all stakeholders in decision-making. The importance of institutions, local communities, and other stakeholders is also reflected in the Concept of Good School (Geros mokyklos koncepcija, 2015). It states that the concept is intended not only for pupils, teachers, school heads, institutions implementing the rights 
and responsibilities of ownership of schools, but also for pupils' parents, the whole society. The Concept of Good School aims that a vision and strategy of the school would be created by school staff, pupils and their parents, as well as by local community and the institution implementing the rights and responsibilities of school ownership, everyone has to take responsibility for the implementation of the goals. The emphasis is placed on strong relationships between pupils' parents and teachers, and this ensures the implementation of educational goals. The Concept of Good School states that any member of the school community can be the initiator and leader of activities and events. Attention is paid to distributed leadership: the majority of the decisions are made by the school community, the activities of which are led by its various members, as well as personal initiative is promoted (Geros mokyklos koncepcija, 2015).

The Law on Education (Law on Education, 1991) stipulates that the highest authority of educational institutions is the school council which consists of pupils, teachers, parents (guardians, caretakers) and representatives of the local community. The school council, in accordance with the competence defined in the school regulations, makes decisions, influences the decisions made by the head, and conducts the public supervision of school management. However, the issue of liability of the institution's council remains unclear, it is not defined neither in the Law on Education of the Republic of Lithuania nor in the regulations of the institutions or in other legal documents. In this case, as R. Xu, Q. Sun, W. Si (2015) observe, there is a conflict between decentralization of management and accountability as well as responsibility at the same time. Although legal documents regulate and emphasize the importance of the community in addressing the management issues of educational institution, the question arises whether these institutions face the challenge highlighted by J. Torfing and P. Triantafillou (2013), i.e. whether the community of the institution actively and willingly participates in a decentralized process of management.

To summarize, the ideas of new public governance and distributed leadership of educational institutions are closely linked. There are a number of common features of new public governance model and distributed leadership of educational institutions, such as: decentralized management, collegial organizational structure, leadership as interaction. Similar challenges are observed as well: the issue of "empowering" society / community, responsibility and accountability.

\section{Conclusions}

Currently, distributed leadership is the dominant idea of management and is characterized by the following features in an organization: the participation of all employees in the activities of the organization, professional sharing of available skills with each other, learning from each other, communication and cooperation to achieve the goals of the organization, high confidence in each other, taking responsibility and accountability for their own activity and collective results, participation in decision-making, distribution of power and activity among formal and informal leaders. The competences of formal leaders are very important in the development of distributed leadership in educational institutions. It depends on formal leaders, whether the appropriate conditions will be created for the manifestation of leadership of employees.

The new normative legal documents outlining the strategic direction of Lithuania and providing the guidelines for the state education system show the state's aim to change the Lithuanian educational system, i.e. to conduct the changes of values in educational institutions, to strengthen the role of communities in the management of organizations, and to change the culture of management of educational organizations. However, the implementation of leadership ideas in Lithuanian educational institutions is not strictly regulated. Therefore, each organization can independently make decisions in order to optimize the decisions of the organization, or to take no action if the obvious organizational and structural changes in the organization are not required by the institutions controlling the activities of educational institutions. However, in case formal leaders are not interested in implementing the ideas of distributed leadership in their organization, on the basis of normative legal documents, the community itself has an opportunity to require cultural and structural changes in the organization.

The ideas of new public governance and distributed leadership of educational institutions are closely interlinked, as both are characterized by the following factors: decentralized management, collegial organizational structure, leadership as interaction. They both face similar challenges, i.e. the problem of "empowering" society / community, the issue of responsibility and accountability. 


\section{Bibliography}

1. Bolden R. (2011). Distributed Leadership in Organizations: A Review of Theory and Research. International Journal of Management Reviews, 13, 251-269. Retrieved from https://www.mnsu.edu/activities/leadership/distributed_leadership.pdf

2. Butkevica A., Zobena A. (2017). Teacher Leaders as Agents of Innovation Diffusion. In V. Dislere (Ed.). The Proceedings of the International Scientific Conference Rural Environment. Education. Personality (REEP), 10. Jelgava: LLU TF, 56-62. Retrieved from http://lufb.llu.lv/conference/REEP/2017/Latvia-Univ-Agricult-REEP-2017_proceedings-56-62.pdf

3. Dambrauskiene D., Liukineviciene L. (2017). Possibilities of Distributed Leadership Development in the Context of Changes: A Case of Pre-School education institutions. Management of Organizations: Systematic Research, 78, 33-47. Retrieved from https://dx.doi.org/10.1515/mosr-2017-0014

4. Drysdale L., Gurr D. (2017). Leadership in Uncertain Times. ISEA, 45 (2), 131-159.

5. Duif T., Harrison Ch., van Dartel N. (2013). Distributed Leadership in Practice. A Descriptive Analysis of Distributed Leadership in European Schools. Retrieved from http://josephkessels.com/sites/default/files/duijf_e.a._2013_distributed_leadership_in_practice_e sha-etuce_0.pdf

6. Elmore R.F. (2000). Building a New Structure for School Leadership. Washington: The Albert Shanker Institute. Retrieved from http://www.shankerinstitute.org/sites/shanker/files/building.pdf

7. Geros mokyklos koncepcija (Concept of Good School). (2015). Ministry of Education and Science of the Republic of Lithuania. Retrieved from https://www.smm.lt/ uploads/documents/Pedagogams/Geros\%20mokyklos\%20koncepcija.pdf (in Lithuanian)

8. Gibb C.A. (1954). Leadership. In G. Lindzey (Ed.). Handbook of Social Psychology, 2, 877-917. Reading, MA: Addison-Wesley.

9. Gronn P. (2000). Distributed Properties: A New Architecture for Leadership. Educational Management Administration and Leadership, 28(3), 317-338.

10. Harris A. (2010). Distributed School Leadership: Developing Tomorrow's Leaders. Vilnius: Švietimo aprūpinimo centras/Education Supply Centre.

11. Harris A. (2012). Distributed Leadership: Implications for the Role of the Principal. Journal of Management Development. 31(1), 7-17.

12. Hill A.L. (2008). Distributed Leadership in Schools. Doctoral Thesis. Australia: The University of Melbourne. Retrieved from https://minervaaccess.unimelb.edu.au/bitstream/handle/11343/39489/74688_ALHill.pdf?sequence=1\&isAllowed=y

13. Ivanova M., Ignatjeva S. (2018). Harmonization of Organizational Culture Values and Personal Values in Public Sector. In V. Dislere (Ed.), The Proceedings of the International Scientific Conference Rural Environment. Education. Personality (REEP), 11. Jelgava: LLU TF, 364-372. Retrieved from http://llufb.1lu.lv/conference/REEP/2018/Latvia_REEP_2018_proceedings_ISSN2255808X.pdf

14. Kvalifikaciniu reikalavimu valstybiniu ir savivaldybiu svietimo istaigu (isskyrus aukstasias mokyklas) vadovams aprasas (Qualification Requirements for the Heads of State and Municipal Educational Institutions (Except for Higher Education Institutions). (2011). Ministry of Education and Science of the Republic of Lithuania. Retrieved from https:/eseimas.lrs.lt/portal/legalAct/1t/TAD/TAIS.403446/uzPNJAFJmW (in Lithuanian)

15. Law on Education. (1991). Seimas of the Republic of Lithuania. Retrieved from https://eseimas.lrs.1t/portal/legalAct/en/TAD/TAIS.21110

16. Leithwood K., Day Ch., Sammons, P., Harris A., Hopkins D. (2006). Successful School Leadership. What It Is and How It Influences Pupil Learning. Research report No 800. UK: University of Nottingham. Retrieved from http://webarchive.nationalarchives.gov.uk/20130401151715/http://www.education.gov.uk/public ations/eOrderingDownload/RR800.pdf

17. Lyderiu laikas (Time for Leaders). (2019). Retrieved from http://www.lyderiulaikas.smm.lt/en/about-the-project 
18. Murphy J., Smylie M., Mayrowetz D., Seashore K.L. (2009). The Role of the Principal in Fostering the Development of Distributed Leadership. School Leadership and Management, 29(2), 181-214. Retrieved from https://www.tandfonline.com/doi/abs/10.1080/13632430902775699

19. National Progress Strategy "Lithuania 2030". (2013). Retrieved from https://rio.jrc.ec.europa.eu/en/library/national-progress-strategy-lithuania-2030

20. Nacionaline mokyklu vertinimo agentura (National Agency for School Evaluation). (2018). Retrieved from http://www.nmva.smm.lt/vadovu-vertinimas/pretendentu-kompetencijuvertinimas/registracija-vertinimui/ (in Lithuanian)

21. Spillane J.P. (2015). Leadership and Learning: Conceptualizing Relations between School Administrative Practice and Instructional Practice. Societies, 5(2), 277-294. Retrieved from https://www.mdpi.com/2075-4698/5/2/277

22. Torfing J., Triantafillou P. (2013). What's in a Name? Grasping New Public Governance as a Political-Administrative System. International Review of Public Administration, 18(2), 9-25.

23. Valstybine svietimo 2013-2022 metu strategija (The National Lithuanian Education Strategy 2013-2022). (2014). Ministry of Education and Science of the Republic of Lithuania. Retrieved from https://www.sac.smm.lt/wp-content/uploads/2016/02/Valstybine-svietimo-strategija-20132020_svietstrat.pdf (in Lithuanian)

24. Xu R., Sun Q, Si W. (2015). The Third Wave of Public Administration: The New Public Governance. Canadian Social Science, 11(7), 11-21. Retrieved from http://www.cscanada.net/index.php/css/article/view/7354 